\title{
PENGARUH PERBANDINGAN TERIGU DAN TEPUNG KACANG TUNGGAK TERHADAP KARAKTERISTIK CRACKERS
}

\author{
The Effect Comparative of Wheat Flour and Cowpea Flour to Characteristics of Crackers
}

\author{
Putri Anggun Lestari ${ }^{1)}$, N. L. Ari Yusasrini ${ }^{2)}$, A.A. Istri Sri Wiadnyani ${ }^{2)}$ \\ 1) Mahasiswa Ilmu dan Teknologi Pangan, Fakultas Teknologi pertanian, Unud \\ ${ }^{2)}$ Dosen Ilmu dan Teknologi Pangan, Fakultas Teknologi pertanian, Unud \\ PS Ilmu dan Teknologi Pangan, Fakultas Teknologi Pertanian, Universitas Udayana, \\ Kampus Bukit Jimbaran, Badung-Bali
}

\begin{abstract}
This study aims to determine the effect of comparative of wheat and cowpea flour to characteristics of crackers andto knowing the composition to produce crackers with the best characteristics. The experimental design used was Completely Randomized Design with treatment factor that is the comparative treatment of cowpea flour with wheat which consist of 5 levels : 100\%:0\%, 95\%:5\%, 90\%:10\%, 85\%:15\%, and 80\%:205. The treatment was repeated 3 times to obtain 15 units of experiment. The data obtained were analyzed by variance and if the treatment had an effect on the observed variable then continoued with Duncan test. Result of this study showed that comparation of wheat flour and cowpea flour very affected for protein content and coarse fiber content, affected water content, ash content, color, texture, and overall acepatance. Comparation of $80 \%$ wheat flour and $20 \%$ cowpea flour is the best characteristics of crackers with criteria $2.24 \%$ water contet, $2.62 \%$ ash content, $23.93 \%$ fat content, $10.70 \%$ protein content, $61.28 \%$ carbohydrate content, $6.61 \%$ crude fiber content, 0.44 power of broke, the color was liked, the aroma was neutral, the taste was liked and a little typical of cowpea, texture was crunchy and liked, and overall aceptance was liked.
\end{abstract}

Keywords: Crackers, cowpea flour, wheat flour.

\section{PENDAHULUAN}

Crackers adalah jenis biskuit yang dibuat melalui proses fermentasi atau pemeraman, berbentuk pipih yang rasanya mengarah ke asin dan renyah, dan bila dipatahkan penampang potongannya berlapis-lapis (Anonim, 1992).

Bahan baku utama dalam memproduksi crakers adalah terigu dimana sampai saat ini terigu masih diimpor. Menurut BPS (2017) selama ini Indonesia merupakan negara pengimpor gandum terbesar keempat di dunia dengan volume impor mencapai 554 ribu ton pada tahun 2008 dan meningkat menjadi 11,48 juta ton pada tahun 2017. Jika keadaan ini dibiarkan, ketergantungan pangan dari luar negeri dapat meningkatkan pengeluaran devisa negara. Perlu adanya upaya untuk mengurangi ketergantungan penggunaan terigu yaitu dengan beralih pada penggunaan berbagai bahan pangan lokal yang dapat dibuat menjadi tepung.
Pembuatan crackers membutuhkan terigu dengan kandungan protein yang rendah karena tidak memerlukan pengembangan adonan yang terlalu tinggi, sehingga memungkinkan untuk menambahkan bahan lain yang memiliki komponen penyusun yang hampir sama sehingga dapat mengurangi penggunaan terigu. Salah satu bahan yang dapat ditambahkan pada pembuatan crackers adalah tepung kacang tunggak.

Kacang tunggak atau kacang tolo (Vigna unguiculata, L) adalah salah satu jenis kacangkacangan yang sudah dikenal dan dibudidayakan oleh masyarakat. Kandungan protein kacang tunggak sebesar 24,4 g/100g yang berpotensi sebagai sumber protein nabati. Kacang tunggak memiliki kandungan, lemak 1,9 g/100g , karbohidrat 56,6 g/100g, serat $1,6 \mathrm{~g} / 100 \mathrm{~g}$, kalsium $481 \mathrm{mg} / 100 \mathrm{~g}$, dan fosfor $399 \mathrm{mg} / 100 \mathrm{~g}$ (Mahmud et al, 2008). Kacang tunggak juga mengandung serat sebesar $3,7 \mathrm{~g} / 100 \mathrm{~g}$ kacang tunggak.

\footnotetext{
*Korespondensi Penulis:

E-mail: ari_yusasrini@yahoo.com ${ }^{2)}$
} 
Kacang tunggak dapat diolah menjadi tepung dan dapat dimanfaatkan sebagai pembuatan produk yang lebih beraneka ragam. Puspitasari et al, (2015) melaporkan bahwa tepung kacang tunggak dapat digunakan dalam pembuatan biskuit. Penggunaan tepung kacang tunggak sebesar 50\% menghasilkan biskuit dengan karakteristik terbaik.

Pembuatan crackers dengan penambahan tepung kacang tunggak perlu diperhatikan formulasinya, yaitu perbandingan antara terigu dengan tepung kacang tunggak. Apabila digunakan tepung kacang tunggak yang terlalu banyak, maka adonan yang dihasilkan akan kurang elastis, sehingga pada saat pemipihan adonan akan mudah pecah dan susah untuk dilakukan pencetakan, sedangkan jika tepung kacang tunggak yang digunakan terlalu sedikit, peningkatan protein yang diharapkan juga akan kurang maksimal.

Sejauh ini belum ada penelitian yang mengaplikasikan tepung kacang tunggak untuk pembuatan crackers. Oleh karena itu, sangat perlu dilakukan penelitian yang bertujuan untuk memanfaatkan tepung kacang tunggak sebagai bahan pembuatan produk pangan, khususnya pada pembuatan crackers.

\section{METODE PENELITIAN}

\section{Tempat dan waktu penelitian}

Tempat yang digunakan untuk melakukan penelitian ini adalah Laboratorium Pengolahan Pangan, Laboratorium Analisis Pangan dan Laboratorium Rekayasa Proses dan Pengendalian Mutu Fakultas Teknologi Pertanian, Universitas Udayana. Waktu pelaksanaan Februari 2018 sampai Maret 2018.

\section{Bahan dan alat}

Bahan-bahan penelitian: tepung kacang tunggak, terigu kunci biru, margarin, susu skim, ragi, soda kue, garam, gula, dan air. Bahan kimia yang digunakan dalam melakukan analisis proksimat meliputi alkohol, tablet kjeldahl, $\mathrm{HCl}$, aquades, $\mathrm{H}_{2} \mathrm{SO}_{4}, \mathrm{NaOH}$, asam borat, indikator $\mathrm{PP}$, dan heksan.

Alat-alat yang digunakan terdiri dari: kompor gas, waskom, timbangan, cetakan, roller, loyang, timbangan analitik (Metler Toledo AB-204), sendok, tisu, benang wol, kompor listrik, ayakan 80 mesh, aluminium foil, desikator, oven, cawan porselin, kertas saring, kertas whatman No.81, erlenmeyer, pipet volume, gelas beker, buret, pemanas, muffle, labu lemak, gelas ukur, labu kjeldahl, soxhlet, ruang asam, tabung reaksi, sendok, spatula, pinset, eksikator, destilator, dan waterbath, texture analyser (TA.XT.plus).

\section{Rancangan percobaan}

Penelitian ini menggunakan Rancangan Acak Lengkap (RAL) dengan perlakuan perbandingan tepung kacang tunggak dengan terigu yaitu $\mathrm{P} 0$ (0\% : 100\%), P1 (5\% : 95\%), P2 (10\% : 90\%), P3 (15\%: 85\%), dan P4( 20\%: $80 \%$ ). Masing-masing perlakuan diulang sebanyak 3 kali sehingga diperoleh 15 unit percobaan. Data yang diperoleh kemudian dianalisis sidik ragam dan apabila terdapat pengaruh antar perlakuan dilanjutkan dengan uji Duncan.

\section{Pelaksanaan Penelitian \\ Proses Pembuatan Tepung Kacang Tunggak}

Proses pembuatan tepung kacang tunggak yaitu diawali dengan sortasi kacang tunggak guna mendapatkan bahan dengan kualitas yang baik. Kacang yang telah disortasi kemudian dicuci dan direndam selama 14 jam lalu dilakukan pengukusan selama 10 menit. Kacang yang telah dikukus kemudian dikupas kulitnya sehingga dihasilkan kacang tunggak tanpa kulit, lalu dikeringkan. Kacang tunggak yang telah kering inilah yang kemudian digunakan untuk pembuatan tepung kacang tunggak. Kacang tunggak tanpa kulit kemudian digiling dan diayak menggunakan ayakan 60 mesh, sehingga dihasilkan tepung kacang tunggak.

\section{Proses Pembuatan Crackers}

Tahapan dalam pembuatan crackers yaitu diawali dengan melakukan penimbangan bahan yang akan digunakan, yaitu terigu, tepung kacang tunggak, gula halus, baking soda, ragi, garam, susu skim, margarin, dan air. Dicampurkan gula halus, baking soda, ragi, garam, susu skim, terigu, dan tepung kacang tunggak. Kemudian ditambahkan margarin. Adonan diuleni dengan tangan sampai kalis. Adonan kemudian ditutup dengan lap yang telah dibasahi dengan air hangat 
dan difermentasi selama $1 \mathrm{jam}$. Adonan kemudian dipipihkan menjadi lembaran menggunakan roller dengan ketebalan $\pm 2 \mathrm{~mm}$. Dilakukan penambahan filler, yaitu bahan pengisi adonan crackers (margarin dan terigu) pada setengah bagian lembaran, kemudian ditutupkan dengan setengah bagian lainnya lalu lembaran tersebut digiling kembali dengan roller hingga menjadi lembaran lagi dan diulang hingga 2 kali. Lembaran kemudian dilakukan pemotongan dengan ukuran $\pm 3 \times 3 \mathrm{~cm}$. Didiamkan 5 menit, dioven pada suhu $150^{\circ} \mathrm{C}$ selama 30 menit.

\section{Variabel yang diamati}

Variabel yang diamati dalam penelitian ini meliputi kadar air dengan metode pengeringan (Sudarmadji, dkk., 1997), kadar abu dengan metode pengabuan (Sudarmadji, dkk., 1997), kadar lemak dengan metode soxhlet (Sudarmadji, dkk., 1997), kadar protein dengan metode mikro-kjeldahl (Sudarmadji, dkk., 1997), kadar karbohidrat dengan metode Carbohydrate by different (Sudarmadji, dkk., 1997), kadar serat kasar dilakukan dengan metode hidrolisis asam basa (Sudarmadji, dkk., 1997), evaluasi sifat sensoris menggunakan uji hedonik terhadap warna, aroma, rasa, tekstur, dan penerimaan keseluruhan serta uji skoring terhadap rasa dan tekstur (Soekarto, 1985), dan uji daya patah dilakukan dengan menggunakan Texture Analyzer (Lloyd Materials Testing, 2012)

\section{HASIL DAN PEMBAHASAN}

Hasil analisis proksimat (kadar air, kadar abu, kadar lemak, kadar protein, kadar karbohidrat) dapat dilihat pada Tabel 1, kadar serat kasar, dan daya patah dari crackers dengan penambahan tepung kacang tunggak dapat dilihat pada Tabel 2.
Tabel 1. Nilai rata-rata hasil analisis kadar air, kadar abu, kadar lemak, kadar protein, dan kadar karbohidrat.

\begin{tabular}{lccc}
\hline Perlakuan & $\begin{array}{c}\text { Kadar air } \\
(\%)\end{array}$ & $\begin{array}{c}\text { Kadar abu } \\
(\%)\end{array}$ & $\begin{array}{c}\text { Kadar } \\
\text { Protein }(\%)\end{array}$ \\
\hline $\begin{array}{l}\text { P0 } \\
(100: 0)\end{array}$ & $4,35 \pm 1,53 \mathrm{~b}$ & $1,68 \pm 0,29 \mathrm{a}$ & $7,11 \pm 0,78 \mathrm{a}$ \\
P1 & $2,78 \pm 0,03 \mathrm{a}$ & $2,23 \pm 0,08 \mathrm{~b}$ & $7,91 \pm 1,37 \mathrm{a}$ \\
$(95: 5)$ & $2,33 \pm 0,05 \mathrm{a}$ & $2,24 \pm 0,28 \mathrm{~b}$ & $9,42 \pm 0,34 \mathrm{~b}$ \\
P2 & & & \\
$(90: 10)$ & $2,29 \pm 0,46 \mathrm{a}$ & $2,34 \pm 0,29 \mathrm{~b}$ & $10,56 \pm 0,41 \mathrm{~b}$ \\
P3 & & & \\
$(85: 15)$ & & & \\
P4 & $2,24 \pm 0,08 \mathrm{a}$ & $2,62 \pm 0,20 \mathrm{~b}$ & $10,70 \pm 0,36 \mathrm{~b}$ \\
$(80: 20)$ & & & \\
\hline
\end{tabular}

Tabel 1. Lanjutan

\begin{tabular}{lcc}
\hline \multicolumn{1}{c}{ Perlakuan } & $\begin{array}{c}\text { Kadar Lemak } \\
(\%)\end{array}$ & $\begin{array}{c}\text { Kadar Karbohidrat } \\
(\%)\end{array}$ \\
\hline $\begin{array}{l}\text { P0 } \\
(100: 0)\end{array}$ & $21,18 \pm 2,53 \mathrm{a}$ & $65,66 \pm 3,44 \mathrm{a}$ \\
$\begin{array}{l}\text { P1 } \\
(95: 5)\end{array}$ & $22,62 \pm 2,33 \mathrm{a}$ & $64,93 \pm 2,42 \mathrm{a}$ \\
$\begin{array}{l}\text { P2 } \\
(90: 10)\end{array}$ & $23,23 \pm 3,00 \mathrm{a}$ & $62,85 \pm 3,54 \mathrm{a}$ \\
$\begin{array}{l}\text { P3 } \\
(85: 15)\end{array}$ & $23,79 \pm 0,84 \mathrm{a}$ & $60,96 \pm 0,66 \mathrm{a}$ \\
$\begin{array}{l}\text { P4 } \\
(80: 20)\end{array}$ & $23,93 \pm 0,19 \mathrm{a}$ & $61,28 \pm 2,35 \mathrm{a}$ \\
\hline
\end{tabular}

Keterangan : Nilai rata-rata yang diikuti huruf yang sama pada kolom yang sama menunjukkan perbedaan yang tidak nyata $(\mathrm{P}>0,05)$

Tabel 2. Nilai rata-rata hasil analisis kadar serat kasar dan daya patah crackers

\begin{tabular}{lcc}
\hline Perlakuan & $\begin{array}{c}\text { Kadar Serat } \\
\text { kasar }(\%)\end{array}$ & Daya patah (kgf) \\
\hline P0 (100:0) & $2,61 \pm 0,95 \mathrm{a}$ & $0,31 \pm 0,15 \mathrm{a}$ \\
P1 (95:5) & $3,83 \pm 0,43 \mathrm{~b}$ & $0,37 \pm 0,18 \mathrm{a}$ \\
P2 (90:10) & $4,37 \pm 0,46 \mathrm{~b}$ & $0,43 \pm 0,13 \mathrm{a}$ \\
P3 (85:15) & $6,00 \pm 0,57 \mathrm{c}$ & $0,47 \pm 0,24 \mathrm{a}$ \\
P4 (80:20) & $6,01 \pm 0,72 \mathrm{c}$ & $0,44 \pm 0,10 \mathrm{a}$ \\
\hline
\end{tabular}

Keterangan : Nilai rata-rata yang diikuti huruf yang sama pada kolom yang sama menunjukkan perbedaan yang tidak nyata $(\mathrm{P}>0,05)$ 


\section{Kadar Air}

Hasil sidik ragam menunjukkan bahwa perbandingan terigu dengan tepung kacang tunggak berpengaruh nyata $(\mathrm{P}<0,05)$ terhadap kadar air crackers. Tabel 1 menunjukkan bahwa kadar air crackers berkisar antara 2,24\% sampai dengan 4,35\%. Kadar air tertinggi diperoleh dari perlakuan $100 \%$ terigu dan $0 \%$ tepung kacang tunggak yaitu sebesar $4,35 \%$, sedangkan kadar air terendah diperoleh dari perlakuan $80 \%$ terigu dan $20 \%$ tepung kacang tunggak yaitu $2,24 \%$.

Penurunan kadar air terjadi seiring dengan penambahan tepung kacang tunggak. Hal ini dikarenakan kadar air tepung kacang tunggak lebih rendah dibandingkan dengan terigu. Kadar air terigu (kunci biru) adalah sebesar $14,53 \%$, sedangkan kadar air tepung kacang tunggak adalah 7,5\% (Purwani dan Santosa,1996 dalam Utomo, 1998). Kadar air dalam penelitian ini telah memenuhi SNI crackers (SNI. 01-2973-1992) yaitu kadar air maksimal 5\% b/b.

\section{Kadar Abu}

Hasil sidik ragam menunjukkan bahwa perbandingan terigu dengan tepung kacang tunggak berpengaruh nyata $(\mathrm{P}<0,05)$ terhadap kadar abu crackers. Tabel 1 menunjukkan bahwa kadar abu crackers berkisar antara 1,68\% sampai dengan $2,62 \%$. Kadar abu tertinggi diperoleh dari perlakuan $\mathrm{P} 4$ (80\% terigu dan $20 \%$ tepung kacang tunggak), sedangkan kadar abu terendah diperoleh dari perlakuan P0 (100\% terigu dan 0\% tepung kacang tunggak).

Semakin tinggi penggunaan tepung kacang tunggak, maka kadar abu crackers akan semakin tinggi. Hal ini dapat disebabkan karena kadar abu tepung kacang tunggak lebih tinggi dibandingkan dengan terigu, karena pada umunya kacangkacangan memiliki kandungan mineral yang cukup tinggi. Kadar abu tepung kacang tunggak adalah 4,49\% (Purwani dan Santosa,1996 dalam Utomo, 1998), sedangkan kadar abu terigu yang digunakan adalah sebesar $0,63 \%$. Besarnya nilai kadar abu menurut standar mutu crackers maksimal 2, sehingga perlakuan yang memenuhi SNI adalah P0 (100\% terigu dan 0\% tepung kacang tunggak).

\section{Kadar Lemak}

Hasil sidik ragam menunjukkan bahwa perbandingan terigu dengan tepung kacang tunggak berpengaruh tidak nyata $(\mathrm{P}>0,05)$ terhadap kadar lemak crackers. Tabel 1 menunjukkan bahwa kadar lemak crackers berkisar antara 21,18\% sampai dengan $23,79 \%$. Hal ini disebabkan karena kandungan lemak yang dimiliki oleh terigu sama dengan kandungan lemak tepung kacang tunggak yaitu sebesar \pm 1,3\% (Purwani dan Santosa,1996 dalam Utomo, 1998).

\section{Kadar Protein}

Hasil sidik ragam menunjukkan bahwa perbandingan terigu dengan tepung kacang tunggak berpengaruh sangat nyata $(\mathrm{P}<0,01)$ terhadap kadar protein crackers yang dihasilkan. Tabel 1 menunjukkan nilai rata-rata kadar protein crackers tertinggi diperoleh dari perlakuan $\mathrm{P} 4$ (80\% terigu dan $20 \%$ tepung kacang tunggak) yaitu $10,70 \%$, sedangkan kadar protein terendah diperoleh dari perlakuan P0 (100\% terigu dan 0\% tepung kacang tunggak).

Semakin meningkat jumlah tepung kacang tunggak yang digunakan, kadar protein crackers semakin meningkat. Peningkatan kandungan protein ini dikarenakan kandungan protein tepung kacang tunggak lebih tinggi yaitu 23,36\% (Purwani dan Santosa,1996 dalam Utomo, 1998) dibandingkan terigu kunci biru yang hanya memiliki kandungan protein sebesar $8,63 \%$. Kadar protein menurut standar mutu crackers adalah minimal 9\% (Anon., 1992). Perlakuan yang telah memenuhi kriteria SNI adalah P2 (90\% terigu dan 10\% tepung kacang tunggak), P3 (85\% terigu dan $15 \%$ tepung kacang tunggak), dan $\mathrm{P} 4$ ( $80 \%$ terigu dan $20 \%$ tepung kacang tunggak).

\section{Kadar Karbohidrat}

Hasil sidik ragam menunjukkan bahwa perbandingan terigu dengan tepung kacang tunggak berpengaruh tidak nyata $(\mathrm{P}>0,05)$ terhadap kadar karbohidrat crackers yang dihasilkan, sehingga dengan berbagai perlakuan yang diberikan, tidak mempengaruhi kadar crackers yang dihasilkan. Kadar karbohidrat yang dihitung secara Carbohydrate by different dipengaruhi oleh komponen nutrisi lain, semakin rendah komponen nutrisi lain maka kadar 
karbohidrat akan semakin tinggi. Begitu juga sebaliknya semakin tinggi komponen nutrisi lain maka kadar karbohidrat akan semakin rendah. Komponen nutrisi yang mempengaruhi besarnya kandungan karbohidrat diantaranya adalah kandungan protein, lemak, air, dan abu (Sugito dan Hayati, 2006).

\section{Kadar Serat Kasar}

Hasil sidik ragam menunjukkan bahwa perbandingan terigu dengan tepung kacang tunggak berpengaruh sangat nyata $(\mathrm{P}<0,01)$ terhadap kadar serat kasar crackers. Nilai rata-rata hasil analisis kadar serat kasar pada crackers dapat dilihat pada Tabel 2. menunjukkan nilai rata-rata kadar serat kasar crackers tertinggi diperoleh dari perlakuan $\mathrm{P} 4$ (80\% terigu dan $20 \%$ tepung kacang tunggak) sedangkan kadar serat kasar terendah diperoleh dari perlakuan P0 $(100 \%$ terigu dan $0 \%$ tepung kacang tunggak).

Peningkatan kadar serat kasar terjadi dengan semakin bertambahnya tepung kacang tunggak yang diberikan. Hal ini dikarenakan tepung kacang tunggak memiliki kandungan serat kasar yang lebih tinggi yaitu 3,3\% (Purwani dan Santosa, 1996 dalam Utomo, 1998) dibandingkan dengan terigu yang memiliki kandungan serat kasar sebesar 2,5\%.

\section{Daya Patah}

Hasil sidik ragam menunjukkan bahwa perbandingan terigu dengan tepung kacang tunggak berpengaruh tidak nyata $(\mathrm{P}>0,05)$ terhadap daya patah crackers yang dihasilkan. Nilai rata-rata hasil analisis daya patah crackers dapat dilihat pada Tabel 2.

Daya patah pada crackers berkaitan dengan tekstur yang dihasilkan. Jika gaya yang dibutuhkan untuk mematahkan crackers semakin kecil maka dapat disimpulkan bahwa crackers yang dihasilkan semakin renyah. Jadi, dengan semakin besar penambahan tepung kacang tunggak, maka kerenyahan pada crackers yang dihasilkan akan semakin menurun.

\section{Evaluasi Sensoris}

Evaluasi sifat sensoris crackers dilakukan dengan uji hedonik dan uji skoring. Uji hedonik dilakukan terhadap warna, aroma, tekstur, rasa, dan penerimaan keseluruhan. Uji skoring dilakukan terhadap rasa dan tekstur crackers. Nilai rata-rata uji hedonik dan skoring crackers dapat dilihat pada Tabel 3.

Tabel 3. Nilai rata-rata uji hedonik dan uji skoring crackers perbandingan terigu degan tepung kacang tunggak

\begin{tabular}{ccccc}
\hline \multirow{2}{*}{ Perlakuan } & \multicolumn{2}{c}{ Tekstur } & \multicolumn{2}{c}{ Rasa } \\
\cline { 2 - 5 } & Hedonik & Skoring & Hedonik & Skoring \\
\hline P0 & $4,20 \mathrm{~b}$ & $4,13 \mathrm{a}$ & $3,73 \mathrm{a}$ & $2,47 \mathrm{a}$ \\
P1 & $3,93 \mathrm{ab}$ & $3,93 \mathrm{a}$ & $3,73 \mathrm{a}$ & $2,87 \mathrm{ab}$ \\
P2 & $3,80 \mathrm{a}$ & $3,93 \mathrm{a}$ & $3,47 \mathrm{a}$ & $3,13 \mathrm{~b}$ \\
P3 & $3,73 \mathrm{a}$ & $3,80 \mathrm{a}$ & $3,40 \mathrm{a}$ & $3,33 \mathrm{~b}$ \\
P4 & $4,00 \mathrm{ab}$ & $3,93 \mathrm{a}$ & $3,87 \mathrm{a}$ & $3,33 \mathrm{~b}$ \\
\hline
\end{tabular}

Tabel 3. Lanjutan

\begin{tabular}{cccc}
\hline Perlakuan & Warna & Aroma & $\begin{array}{c}\text { Penerimaan } \\
\text { keseluruhan }\end{array}$ \\
\hline P0 & $3,73 \mathrm{a}$ & $3,47 \mathrm{a}$ & $4,13 \mathrm{~b}$ \\
P1 & $3,73 \mathrm{a}$ & $3,67 \mathrm{a}$ & $3,87 \mathrm{ab}$ \\
P2 & $3,47 \mathrm{a}$ & $3,67 \mathrm{a}$ & $3,87 \mathrm{ab}$ \\
P3 & $3,40 \mathrm{a}$ & $3,67 \mathrm{a}$ & $3,60 \mathrm{a}$ \\
P4 & $3,87 \mathrm{a}$ & $3,43 \mathrm{a}$ & $4,07 \mathrm{~b}$ \\
\hline
\end{tabular}

Keterangan : Huruf yang sama di belakang nilai rata-rata pada kolom yang sama menunjukkan perbedaan yang tidak nyata $(\mathrm{P}>0,05)$

Kriteria hedonik : 1 (sangat tidak suka), 2 (tidak suka), 3 (netral), 4 (suka), 5 (sangat suka).

Kriteria uji skoring tekstur : 1 (sangat tidak renyah), 2 (tidak renyah), 3 (kurang renyah), 4 (renyah), 5 (sangat renyah)

Kriteria uji skoring rasa : 1 (Sangat tidak khas kacang tunggak), 2 (Tidak khas kacang tunggak), 3 (Kurang khas kacang tunggak), 4 (Khas kacang tunggak), 5(Sangat Khas kacang tunggak)

\section{Warna}

Hasil sidik ragam menunjukkan bahwa perbandingan terigu dengan tepung kacang tunggak berpengaruh nyata $(\mathrm{P}<0,05)$ terhadap warna crackers. Tabel 3 menunjukkan nilai rata- 
rata tingkat kesukaan panelis terhadap warna crackers yang tertinggi yaitu perlakuan $95 \%$ terigu dan 5\% tepung kacang tunggak yaitu suka, sedangkan nilai rata-rata terendah diperoleh dari perlakuan $85 \%$ terigu dan $15 \%$ tepung kacang tunggak yaitu suka.

Perbedaan karakteristik warna pada crackers tepung kacang tunggak dapat disebabkan karena kacang tunggak mengandung pigmen antosianin yang berwara gelap merah kecoklatan dan juga disebabkan oleh adanya reaksi pencoklatan yaitu reaksi Maillard, reaksi ini terjadi karena adanya reaksi antara gula pereduksi dengan gugus amin bebas dari asam amino atau protein sehingga warna tepung yang dihasilkan memiliki warna putih kecoklatan.

\section{Aroma}

Hasil sidik ragam menunjukkan bahwa perbandingan terigu dengan tepung kacang tunggah berpengaruh tidak nyata $(\mathrm{P}>0,05)$ terhadap aroma crackers. Berdasarkan Tabel 3 keseluruhan perlakuan mendapatkan nilai rata-rata 4 yang artinya suka.

\section{Tekstur}

Hasil sidik ragam ada uji hedonik menunjukkan bahwa perbandingan terigu dengan tepung kacang tunggak berpengaruh nyata $(\mathrm{P}<0,05)$ terhadap tekstur crackers. Tabel 3 menunjukkan nilai rata-rata tingkat kesukaan panelis terhadap tekstur crackers yang tertinggi yaitu perlakuan $100 \%$ terigu dan $0 \%$ tepung kacang tunggak yaitu suka, sedangkan nilai ratarata terendah diperoleh dari perlakuan $85 \%$ terigu dan $15 \%$ tepung kacang tunggak yaitu suka.

Hasil sidik ragam pada uji skoring menunjukkan bahwa perbandingan terigu dengan tepung kacang tunggak berpengaruh tidak nyata $(\mathrm{P}>0,05)$ terhadap tekstur crackers. Berdasarkan Tabel 3 menunjukkan bahwa keseluruhan perlakuan mendapatkan nilai rata-rata 4 yang artinya renyah.

Tekstur pangan ditentukan oleh kadar air, kadar lemak dan kandungan karbohidrat struktural seperti selulosa, pati serta protein yang terkandung dalam suatu produk. Protein dapat meningkatkan kemampuan gelasi sehingga dapat membentuk fleksibilitas atau kemampuan protein untuk terdenaturasi dan membentuk jaringan dengan ikatan silang. Tekstur memiliki pengaruh penting terhadap produk misalnya dari tingkat kerenyahan, tipe permukaan, kekerasan dan sebagainya (Zulhanifah, 2015).

\section{Rasa}

Hasil sidik ragam pada uji hedonik menunjukkan bahwa perbandingan terigu dengan tepung kacang tunggak berpengaruh tidak nyata $(\mathrm{P}>0,05)$ terhadap rasa crackers. Tabel 3 menunjukkan bahwa nilai rata-rata keseluruhan perlakuan adalah 3 yang artinya netral.

Hasil sidik ragam pada uji skoring menunjukkan bahwa perbandingan terigu dengan tepung kacang tunggak berpengaruh sangat nyata $(\mathrm{P}<0,01)$ terhadap rasa crackers. Nilai rata-rata tertinggi diperoleh dari crackers dari perlakuan $80 \%$ terigu dan $20 \%$ tepung kacang tunggak yaitu agak has kacang tunggak, sedangkan perlakuan terendah diperoleh dari perlakuan $100 \%$ terigu dan $0 \%$ tepung kacang tunggak yaitu tidak khas kacang tunggak. Peningkatan rasa khas kacang tunggak disebabkan karena semakin bertambahnya penambahan tepung kacang tunggak.

\section{Penerimaan Keseluruhan}

Hasil sidik ragam menunjukkan bahwa perbandingan terigu dengan tepung kacang tunggak berpengaruh nyata $(\mathrm{P}<0,05)$ terhadap penerimaan keseluruhan crackers. Berdasarkan Tabel 3 Nilai rata-rata tingkat kesukaan panelis terhadap penerimaan keseluruhan crackers yang tertinggi diperoleh dari perlakuan $100 \%$ terigu dan $0 \%$ tepung kacang tunggak yaitu suka, sedangkan nilai rata-rata terendah diperoleh dari perlakuan $85 \%$ terigu dan $15 \%$ tepung kacang tunggak yaitu netral. Penerimaan panelis terhadap penerimaan keseluruhan dipengaruhi oleh beberapa faktor seperti warna, aroma, tekstur, dan rasa crackers.

\section{KESIMPULAN DAN SARAN}

\section{Kesimpulan}

Berdasarkan hasil penelitian ini, maka dapat disimpulkan beberapa hal sebagai berikut :

1) Perbandingan terigu dengan kacang tunggak berpengaruh sangat nyata terhadap kadar 
protein, dan kadar serat kasar, berpengaruh nyata terhadap kadar air, kadar abu, warna, tekstur, dan penerimaan keseluruhan crackers.

2) Crackers dengan karakteristik terbaik diperoleh dari perbandingan $80 \%$ terigu dan $20 \%$ tepung kacang tunggak dengan kadar air $2,24 \%$, kadar abu 2,62\%, kadar lemak $23,93 \%$, kadar protein $10,70 \%$, kadar karbohidrat 61,28\%, kadar serat kasar 6,61\%, daya patah 0,44 kgf, warna suka, aroma netral, tekstur suka dan renyah, rasa netral dan agak khas kacang tunggak, dan penerimaan keseluruhan adalah suka.

\section{Saran}

Berdasarkan hasil penelitian ini dapat disarankan perlu dilakukan pembuatan crackers dengan menggunakan tepung kacang tunggak sebesar $20 \%$.

\section{DAFTAR PUSTAKA}

Anonimous. 1979. Daftar Komposisi Bahan Makanan. Direktorat Gizi Departemen Kesehatan Republik Indonesia. Bharata Karya Aksara. Jakarta.

Anonimous. 1992. SNI. 01.2973.1992. Syarat Mutu Biskuit. Badan Standardisasi Nasional, Jakarta.

Anonimous. 2006. SNI. 01.3751.2006. Syarat Mutu Terigu. Badan Standasdisasi Nasional, Jakarta.

Anonimous. 2017. Crispy Crackers. https://www.fatsecret.co.id. Diakses pada tanggal 20 Oktober 2017

Astawan, M. 2008. Membuat Mie dan Bihun. Penebar Swadaya. Jakarta

$\begin{array}{crr}\text { Driyani, Y. 2007. Biscuit } & \text { Crackers } & \text { Substitusi } \\ \text { Tepung Tempe } & \text { Kedelai } & \text { Sebagai } \\ \text { Alternatif Makanan } & \text { Kecil } & \text { Bergizi } \\ \text { Tinggi. Skripsi. UNNES. Semarang. }\end{array}$

Ferazuma, H., Marliyati, S.A., Amalia, L. 2011. Substitusi tepung kepala ikan lele dumbo (Clarias gariepinus sp.) untuk meningkatkan kandungan kalsium crackers. Jurnal Gizi Pangan. (6(1) : 18-27

Gomes, K. A. dan A. A. Gomes. 1995. Prosedur Statistik Untuk Penelitian Pertanian. UI Press. Jakarta.

Khadafi, M. 2007. Studi Pemanfaatan Tepung Rumput Laut dalam Pembuatan Crackers. Skripsi. Fakultas Perikanan dan Ilmu Kelautan. Universitas Riau. Pekanbaru

Koswara, S. 2009. Teknologi Pengolahan Roti. eBookPangan.com

Mahmud, M.K., N.A. Hermana, I. Zulfianto, R. R. Ngadiart, B. Apriyantono, Hartati, Bernadus dan Tinexelly. 2008. Tabel Komposisi Pangan Indonesia. Pt. Elex Media Komputindo. Kompas Gramedia. Jakarta

Nurizki, R. Y. 2017. Pengaruh Perbandingan Tepung Labu Kuning dengan Tepung Jagung dan Lama Pemanggangan terhadap Sifat Fisikokimia Flakes Labu Kuning. Skripsi. Tidak dipublikasikan. Universitas Pasundan. Bandung

Peranginangin, R.S., Wibowo, dan Y.N. Easy. 1999. Teknik Pengolahan Surimi. Balai Penyuluhan Perikanan Laut. Puslitbang Perikanan. Jakarta.

Puspitasari, D. 2015. Karakterisasi dan Formulasi Tepung Komposit Kimpul-Kacang Tunggak Untuk Pengembangan Biskuit Non Terigu. Universitas Wijaya Kusuma. Surabaya. Prosiding Seminar Agroindustri dan Lokakarya Nasional FKPT-TPI

Rakhmawati, N. 2013. Formulasi Dan Evaluasi Sifat Sensoris Dan Fisikokimia Produk Flakes Komposit Berbahan Dasar Tepung Tapioka, Tepung Kacang Merah Dan Tepung Konjac. Skripsi. Tidak dipublikasikan. UNS. Surakarta.

Rosida, 2013. Kajian Dampak Substitusi Kacang Tunggak pada Kualitas Fisik dan Kimia Tahu. Jurnal UPN Veteran. FTI UPN Veteran.Jatim. 
Soekarto, S.T. 1985. Penilaian Organoleptik Untuk Industri Pangan dan Pertanian. Bharata Karya Aksara : Jakarta.

Sudarmadji, S., B. Haryono dan Suhardi. 1997. Prosedur Analisa untuk Bahan Makanan dan Pertanian. Penerbit Liberty. Yogyakarta.

Sudarmadji, S., B. Haryono dan Suhardi. 2010. Analisa Bahan Makanan dan Pertanian. Liberty : Yogyakarta.

Sugito dan A. Hayati. 2006. Penambahan daging ikan gabus (Ophicepallus strianus) dan aplikasi pembekuan pada pembuatan pempek gluten. Jurnal Ilmu-Ilmu Pertanian Indonesia Vol. 14 (1) : 9-20

USDA. 2008. Nutrition Facts of Mung Bean, Mature Seeds, Raw. http://www.nutritiondata.com. (18 Oktober 2017)

Utomo, J.S., S.S. Antarlina. 1998. Teknologi Pengolahan dan Produk-Produk Kacang Tunggak . Balai Penelitian Tanaman Kacang-Kacangan Dan Umbi-Umbian. Monograf balit kabino $3: 120-138$

Zulhanifah, M. 2015. Pengaruh Perbandingan Tepung Biji Kacang Koro Pedang dengan Tepung Tempe Kacang Koro Pedang terhadap Karakteristik Flakes. Skripsi. UNPAS. Bandung. 
